Check for updates

Montreal

Cite this as: BMJ 2021;374:n1766 http://dx.doi.org/10.1136/bmi.n1766 Published: 12 July 2021

\section{Covid-19: Turkmenistan becomes first country to make vaccination mandatory for all adults}

\author{
Owen Dyer
}

Turkmenistan will legally require all residents over 18 to be vaccinated against the coronavirus, the country's health ministry said on 7 July. Only those with medical contraindications will be exempted.

Turkmenistan's vaccine laws will be the strictest in the world, surpassing those of Saudi Arabia, which since March has operated a broad "no jab, no job” policy in both public and private sectors.

Turkmenistan also announced new mask and social distancing requirements, although it has yet to acknowledge any covid-19 deaths. The government of President Gurbanguly Berdymukhamedov has drawn criticism from the World Health Organization for its refusal to provide data on covid cases and deaths, a stance it now shares only with North Korea. Other formerly reluctant countries like Tanzania and Nicaragua have begun reporting.

Berdymukhamedov reiterated his claim that his country is covid-free at a televised government meeting on 29 June, but in the same comments he repeated previous complaints about a need for more effective vaccines.

Turkmenistan's announcement follows recent moves in neighbouring Russia and Kazakhstan to require vaccination from broad categories of workers, as a third-or in some cases fourth-wave appears to be gathering strength in the region.

Kazakhstan has required all employers from a broad range of industries-including transport, retail, banking, and communications - to vaccinate their workers since 2 July. Since mid-June, it has required businesses in the hospitality, education, healthcare, and entertainment sectors to ensure that $60 \%$ of staff are vaccinated.

\section{Other countries}

But other, less centralised countries are also moving towards mandatory vaccination of large sectors of their populations. Greece will next week announce which categories of jobs are to be included in new national vaccine laws, government spokesperson Aristotelia Peloni said on 8 July.

France's government said on 7 July that it was preparing a law to make coronavirus vaccination mandatory for healthcare workers. "It's a question of responsibility. We will have a mandatory vaccination for the people that are, every day, in contact with the most fragile people in the French population,” finance minister Bruno Le Maire told CNBC.

Fiji's government said on 9 July that it will enforce vaccination for all employees. "It does not matter if you are the chief executive of a company, a sole trader, or a salaried employee," said Fiji's prime "You must be vaccinated to continue working or else that business will risk being shut down. No jabs, no job-that is what the science tells us is safest and that is now the policy of government and enforced through law."1 legislation which would make vaccination mandatory for public service employees, health workers, social workers, and teachers, among others. It will also authorise private employers to dismiss staff who have not obtained vaccination certificates by 15 September. Opposition parties have vowed to block the law. ${ }^{2}$

In Turkmenistan, the number of current cases remains a state secret, but neighbouring Iran is reporting a major surge, as are Russia, Kazakhstan, and Uzbekistan. There are no reliable statistics from Turkmenistan, which some experts say is overestimating its population by a factor of two to hide massive depopulation in recent years, as workers fled to Russia, Uzbekistan, and Turkey. ${ }^{3}$ The country refused to release the results of its last census in 2012.

The central Asian countries with the highest vaccination rates are Azerbaijan and Kazakhstan, where $23 \%$ and $21 \%$ of the populations have received at least one dose. That figure falls to $3.7 \%$ in Tajikistan, 2.3\% in Armenia, and 1.9\% in Kyrgyzstan. Turkmenistan does not release figures. Most countries in the region have used Russian and Chinese vaccines, as well as limited supplies of the AstraZeneca vaccine.

Research published in May by the University of Washington's Institute for Health Metrics and Evaluation found that central Asia and Eastern Europe are the regions hardest hit by the covid-19 pandemic, but that governments there have seriously undercounted cases and deaths. ${ }^{4}$

\footnotetext{
Panapasa G. No jabs, no job: Fiji threatens unvaccinated workers with sack. Guardian. 9 July 2021. www.theguardian.com/world/2021/jul/09/no-jabsno-job-fiji-threatens-unvaccinated-workers-with-sack.

2 Opposition MPs planning to demand popular vote on "mandatory vaccination.” Baltic Times. 8 July 2021. www.baltictimes.com/opposition_mps_planning_to_demand_popular_vote_on_mandatory_vaccination_.

3 Sources: Turkmenistan in a state of depopulation. There are 2.7 million population left in the country. Radio Azatlyk. 2 July 2021. https://rus.azathabar.com/a/turkmenistan-in-state-of-depopulation-with-under-threemillion-people/31338392.html.

4 Institute for Health Metrics and Evaluation. Estimation of excess mortality due to covid-19. 13 May 2021. www.healthdata.org/special-analysis/estimation-excess-mortality-due-covid-19-and-scalars-reported-covid-19deaths.
}

This article is made freely available for use in accordance with BMJ's website terms and conditions for the duration of the covid-19 pandemic or until otherwise determined by BMJ. You may use, download and print the article for any lawful, minister, Frank Bainimarama, in a televised speech.

Latvia's government is currently advancing 
non-commercial purpose (including text and data mining) provided that all copyright notices and trade marks are retained. 